Cell-free and whole-tissue protein synthesis was studied in skeletal muscle of untrained male guinea pigs that had undergone a treadmill run to exhaustion. Experiments using explants from the gastrocnemius muscle maintained in organ culture demonstrated that the ability of the acutely exercised muscle to incorporate amino acids into protein had increased. Compared to polyribosomes prepared from several lower hind limb muscles of nonexercised guinea pigs, polyribosomes from the same muscle in exhausted guinea pigs had incorporated almost $50 \%$ more radioactive leucine into protein. However, the polysome profiles of control and exercised muscle were identical, and no difference in the total polysome RNA content could be detected. The efficiency of in-vitro protein synthesis using washed membranebound polyribosomes (microsomes) isolated from acutely exercised skeletal muscle was $50 \%$ greater than with microsomes from rested control muscle.

\title{
PROTEIN SYNTHESIS IN SKELETAL MUSCLE FOLLOWING ACUTE EXHAUSTIVE EXERCISE
}

PETER A. ROGERS, BSc, GeORGE H. JONES, PhD, and JOHN A. FAULKNER, PhD

The protein synthesis system in mature mammalian skeletal muscle demonstrates the capacity to respond and adapt to various pathologic states as well as to changes in functional demand. For example, various differences in the ribosomal capacity for protein synthesis have been observed in several types of muscular dystrophy, ${ }^{6}$ and diabetes decreases the capacity of skeletal muscle to synthesize protein in vitro ${ }^{9}$ and in vivo. ${ }^{3}$ Microsomal and ribosomal protein synthesis is decreased in the skeletal muscles of rats after four to six days of protcin starvation, and is enhanced after a single meal of protein. ${ }^{14}$ The effects of changes in dietary regimen can be detected in vivo as well, ${ }^{10}$ and these studies have correlated well with in-vitro results.

From the Department of Cellular and Mclecular Biology. Division of Biological Sciences (Mr. Rogers and Dr. Jones), and Department of Physiology (Dr. Faulkner), University of Michigan, Ann Arbor, MI.

Acknowledgments: This research was supported by grants from the $\mathrm{Na}$ tional Cancer Institute and the Michigan Memorial Phoenix Project.

Address reprint requests to Dr. Jones at the Department of Cellular and Molecular Biology, University of Michigan Division of Biological Sciences, Ann Arbor, Ml 48109

Received for publication March 24, 1978; revised manuscript accepted for publicátion January 11,1979

0148-639x/0204/0250\$00.00/0

1979 Houghton Mifflin Professional Publishers
An increase in the capacity for microsomal protein synthesis has been reported for skeletal muscle undergoing hypertrophy ${ }^{2}$ and for cardiac muscle subjected to increased functional demand in vitro. ${ }^{13}$

Our experiments were designed to investigate the capacity for protein synthesis by tissue explants, microsomes, and polyribosomes isolated from the lower hind limb of guinea pigs $1 \mathrm{hr}$ after a single bout of vigorous exercise (running on a motor-driven treadmill). The observations indicate that the exercised skeletal muscle, removed from in-vivo neural and hormonal influence, incorporates amino acids into protein more efficiently than similarly isolated, nonexercised muscle.

\section{MATERIALS AND METHODS}

Animals and Experimental Treatment. Mature, untrained male guinea pigs (Charles River), weighing $600-800 \mathrm{~g}$, were used in all experiments. The experimental groups of animals were run to exhaustion on a motor-driven treadmill at a rate of 0.6 miles per hour on a $10 \%$ incline. Failure of the animals to respond to stimulation by low-voltage electrical shocks served as the criterion for exhaustion. I'he mean running time to cxhaustion under these conditions was $58 \mathrm{~min}$. One hour following exhaustion, the animals were sacrificed by cervical dislocation. Control animals were handled 
in an identical manner except that they were not run on the treadmill but did reccive electrical stimulation comparable to exercised animals. Animals had free access to food and water at all times.

Preparation of Subcellular Fractions. After the animals were sacrificed, selected skeletal muscle (extensor digitorium longus, plantaris, soleus, and gastrocnemius) of the lower hind-limb was removed and dissected free of all obvious connective tissue and fat. The tissue (mean yield, $4.2 \mathrm{~g}$ per animal) was then placed in a chilled Petri dish containing $10 \mathrm{ml}$ of medium A $(0.25 \mathrm{mM}$ sucrose, $10 \mathrm{mM} \mathrm{MgCl}, 250 \mathrm{mM} \mathrm{KCl}, 50 \mathrm{mM}$ Tris-HCl buffer, $\mathrm{pH}$ 7.6). Unless otherwise specified, all subsequent procedures were performed at $4^{\circ} \mathrm{C}$ using ice-cold apparatus and solutions.

The isolated skeletal muscle (equal weights of control or experimental tissue) was minced as finely as possible with scissors in the Petri dish. The minced tissue was homogenized in two volumes of medium A for two separate periods of $15 \mathrm{sec}$ each in a Polytron tissue homogenizer (Brinkman Instruments, Westburg, NY) with a setting of 3 . The homogenates were centrifuged at $10,000 \times \mathrm{g}$ for $15 \mathrm{~min}$ in a Sorvall refrigerated centrifuge ( $\mathrm{Du}-$ pont Instruments, Newton, ('I). The heavy fat layer which appeared was removed by filtration, and the resulting postmitochondrial supernatant was then centrifuged at $105,000 \times \mathrm{g}$ in a Beckman L2-50 ultracentrifuge (Beckman Instruments, Fullerton, CA) for $60 \mathrm{~min}$. The resulting microsomal pellet was dispersed by stirring with a small magnetic stirring bar and resuspended in medium $\mathrm{A}$. Aggregates in the final microsomal preparation were removed by low-speed centrifugation.

Polyribosomes were prepared from microsomal fractions by extending the $105,000 \times \mathrm{g}$ centrifugation to $150 \mathrm{~min}$. The microsomal pellet prepared in this manner was resuspended in medium B $\left(3 \mathrm{ml}\right.$ of $2.5 \mathrm{M} \mathrm{KCl}$ in $10 \mathrm{mM} \mathrm{MgCl}_{2}$ added to $9.75 \mathrm{ml}$ of medium A). The suspension was treated with $10 \%$ deoxycholate (sodium salt, Sigma Chemical Co., St. Louis, MO) and 10\% Lubrol WX to achieve final concentrations of $1 \%$ and $0.5 \%$, respectively. The detergent-treated suspension was left on ice for $10 \mathrm{~min}$ and then layered over $10 \mathrm{ml}$ of $1.0 \mathrm{M}$ sucrose in medium $\mathrm{A}$, henceforth referred to as the sucrose cushion. The suspension was centrifuged at $150,000 \times \mathrm{g}$ for $150 \mathrm{~min}$ to collect the washed polyribosomes. The resulting clear pellet had an absorption coefficient $\left(\mathrm{A}_{260 / 280}\right)$ of 1.7 (mean value for control and experimental preparations) and was resuspended in medium $\mathrm{A}$ by gentle stirring as above. Aggregates were removed by low-speed centrifugation.

The high-speed-supernatant fractions, S150, prepared by taking small aliquots $(0.5-1 \mathrm{ml})$ of the $150,000 \times \mathrm{g}$ supernatant were chromatographed on a column $(1 \times 30 \mathrm{~cm})$, Sephadex G25 (Pharmacia), previously equilibrated with medium A and eluted with the same medium. The material eluting in the void volume was collected and stored in aliquots of $100 \mu \mathrm{l}$.

Assay of Amino Acid Incorporation. Incubation mixtures were prepared containing either microsomes or polyribosomes (refer to figures 3 and 4 for exact quantities), $100 \mu \mathrm{l}$ of the $\$ 150$ fraction (5 mg protein $/ \mathrm{ml}$ ), and $50 \mu \mathrm{l}$ of a master reaction mixture. The final concentrations of reagents in the $100-\mu l$ incubation mixtures were $45 \mathrm{mM}$ Tris- $\mathrm{HCl}, \mathrm{pH}$ $7.6 ; 8 \mathrm{mM} \mathrm{MgCl} 2 ; 10 \mathrm{mM} \beta$-mercaptoethanol; $130 \mathrm{mM} \mathrm{KCl} ; 1.2 \mathrm{mM}$ ATP; $0.1 \mathrm{mM}$ guanosinetriphosphate, $20 \mathrm{mM}$ creatine phosphate; $50 \mu \mathrm{g} /$ $\mathrm{ml}$ creatine kinase; $100 \mu \mathrm{Ci} / \mathrm{ml}\left[{ }^{3} \mathrm{H}\right]$-leucine (New England Nuclear, Boston, MA, $47 \mathrm{Ci} / \mathrm{mmole}$ ); and a mixture of the remaining 19 common amino acids, each at a concentration of $10 \mu \mathrm{M}$. The assay was initiated by the addition of either microsomes or polyribosomes, and the mixtures were incubated at $37^{\circ} \mathrm{C}$ for $30 \mathrm{~min}$. The reaction was terminated by the addition of $4 \mathrm{ml}$ of $10 \%$ trichloroacetic acid (TCA). The incubation mixtures were heated at $90^{\circ} \mathrm{C}$ for $10 \mathrm{~min}$, and the precipitated protein was collected on glass fiber filters (Whatman) by filtration and washed with $10 \%$ TCA. The filters were dried and placed in vials with $7 \mathrm{ml}$ of an Omnifluor-toluene (New England Nuclear Corp., Boston, MA) scintillation cocktail and counted in a Beckman LS-250 liquid scintillation counter.

Sucrose Density Gradient Analysis of Polyribosomes. A $10,000 \times \mathrm{g}$ postmitochondrial supernatant was treated as described above for the preparation of subcellular fractions. Aliquots of $0.4 \mathrm{ml}$ were layered onto a $10 \%-40 \%$ linear sucrose density gradient prepared in homogenization medium. Gradients were centrifuged in a Beckman SW 50-1 at $189,000 \times \mathrm{g}$ and $4^{\circ} \mathrm{C}$ for $30 \mathrm{~min}$. Fractions were collected from the bottom of the tubes, and the absorbance of each fraction at $260 \mathrm{~nm}$ was determined.

Preparation of Tissue Slices and Measurement of Amino Acid Incorporation into Protein. Slices $\left(1 \mathrm{~mm}^{3}\right)$ were prepared from the gastrocnemius and soleus 
muscles of control and experimental guinea pigs. The tissue was incubated in a modified KrebsRinger phosphate buffer ( $\mathrm{pH}$ 7.4), containing 11 $\mathrm{mM}$ glucose, $0.05 \mathrm{mCi}\left[{ }^{3} \mathrm{H}\right]$-leucine, and a complete set of the remaining amino acids at the concentration found in rat plasma. ${ }^{8}$ Tissue was incubated at $37^{\circ} \mathrm{C}$ with continuous gentle shaking and removed for the assay of protein synthesis at the time points indicated in the appropriate figure. The tissue was washed three times in standard Krebs-Ringer buffer containing $1 \mathrm{mM}$ leucine. Trichloroacetic acid to a final concentration of $10 \%$ was added, and the mixture was heated to $90^{\circ} \mathrm{C}$ for $20 \mathrm{~min}$. The protein was collected on glass fiber filters, washed with $10 \%$ trichloroacetic acid and ethanol-ether $(1: 1 \mathrm{v} / \mathrm{v})$, and the filters were dried. Tissue samples were solubilized in $1 \mathrm{ml}$ of $0.5 \mathrm{~N}$ $\mathrm{NaOH}$ by heating at $90^{\circ} \mathrm{C}$ for $30 \mathrm{~min}$. Aliquots were then removed for liquid scintillation counting in a scintillant containing Triton X-100 and for the determination of RNA and protein. Microsomes, polyribosomes, and tissue slices were prepared and assayed for activity on the same day.

Determination of Protein and RNA. Protein in all preparations was assayed by the method of Lowry et al, ${ }^{7}$ and after the removal of protein, RNA was determined by the orcinol method. ${ }^{9}$

\section{RESULTS}

Analysis of Muscle Polyribosomes. By studying the sedimentation of polyribosomal material in sucrose density gradients, it was found that gentle homogenization using the Dounce apparatus (Kontes Glass Co., Vineland, NJ) decreased the yield of polyribosomes by $34 \% \pm 6 \%$ when compared to the more vigorous Polytron homogenizer. No detectable increase in degradation of polyribosomes to ribosome monomers was found using Polytron homogenization.

Linear sucrose density gradient analysis of muscle cell lysates (fig. 1) from exercised and nonexercised muscle tissue revealed no significant differences with respect to yield or distribution of ribosomal or polyribosomal material.

Cell-free Protein Synthesis with Microsomes and Polysomes. Microsomes isolated from the lower hind limb of rested and exercised skeletal muscle were incubated in a protein synthesis system using optimal $\mathrm{K}^{+}, \mathrm{Mg}^{2+}$, ATP, and guanosine triphosphate concentrations. Final reaction mixtures and conditions for optimal protein synthesis were based on the kinetics and extent of the incorporation of $\left[{ }^{3} \mathrm{H}\right]$-leucine into polypeptide. Conditions for protein synthesis with experimental and control microsomes were optimized and identical, and the microsomes showed typical linear incorporation of labeled leucine for the initial 10 min of incubation, after which point a plateau was reached and maintained for at least $30 \mathrm{~min}$ (data not shown).

The results seen in figure 2 indicate that microsomes from control muscle incorporated $1,750 \pm$ 230 counts per min $(\mathrm{cpm})$, while microsomes prepared from exercised skeletal muscle tissue incorporated $3,350 \pm 218 \mathrm{cpm}$. These values are significantly different $(\mathrm{p}<0.01)$. No differences in protein or RNA content between exercised and control microsomes were detected (data not shown).

The in-vitro capacity for protein synthesis was further tested in washed membrane-free polyribosomes prepared as described above. Polyribosomes were initially centrifuged through a 2-M sucrose cushion. Although the activity of polyribosomes prepared in this manner was increased by $14 \pm 3 \%$ when compared to the preparation using a 1-M sucrose cushion, the loss of RNA occasioned by the former procedure was significant, ranging from $20 \%$ to $50 \%$ as compared with the 1-M sucrose procedure. Sucrose density analysis of polyribosomes prepared using a 2-M sucrose cushion suggested either a loss or breakdown of light polyribosomal material during centrifugation; therefore, we have used centrifugation through $1-\mathrm{M}$ sucrose in polysome resuspension buffer in all experiments.

The results presented in figure 3 indicate that polyribosomes prepared from cxercised muscle tissue were significantly more active than corresponding control preparations. In-vitro protein synthesis was carried out under the same conditons used for skclctal muscle microsomes; this proved to be optimal for polyribosomes also. At a concentration of $5 \mu \mathrm{g} / \mathrm{ml}$ polyribosomal RNA, polysomes from exercised muscle tissue incorporated $\mathbf{9 , 8 5 0}$ $\pm 650 \mathrm{cpm}$, while control preparations incorporated $6,000 \pm 540 \mathrm{cpm}$.

As shown in figures 1 and 2, increasing the concentrations of either microsomal protein or polyribosomal RNA inhibited protein synthesis in a ccll-free system. We observed this routinely in all microsome and polyribosome preparations from skeletal muscle. Experiments using mixed sources of microsomes and polyribosomes and $\$ 150$ fraction did not indicate the presence of any inhibitory substances, and the observed decrease in protein synthesis may be analogous to a substrate inhibition effect. 


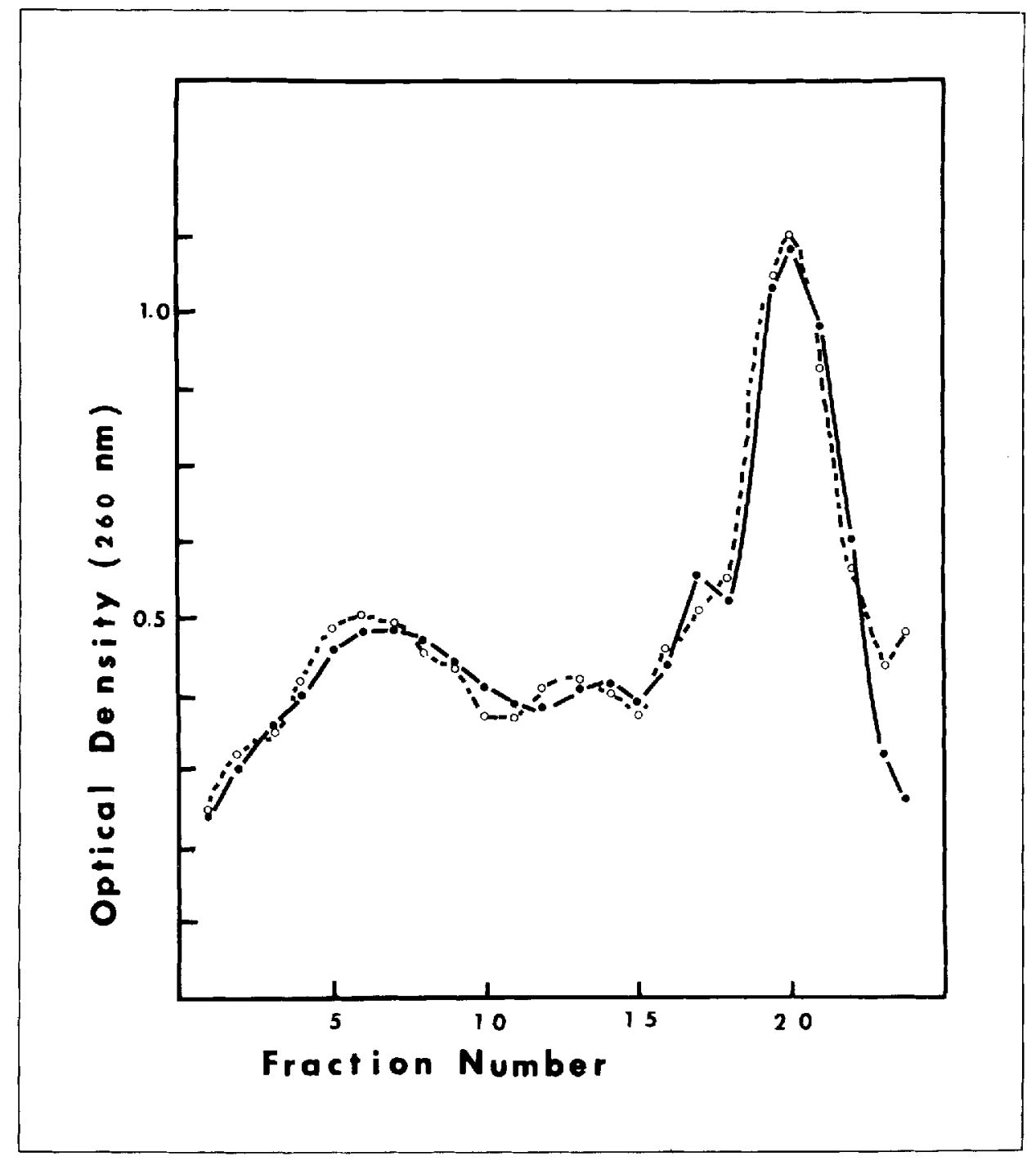

Figure 1. Distribution of polyribosomal and ribosomal material from skeletal muscle cell lysates on a $10 \%-40 \%$ linear sucrose density gradient. Each point represents the mean value of four different preparations. Control (--) and exercised (—) muscle polyribosomes.

Protein Synthesis by Intact Muscle. The gastrocnemius muscle and soleus muscle were used as sources of tissue to measure the protein synthetic activity of explants maintained in organ culture. The incorporation of labeled leucine into protein increased with time in both muscles, between 0.5 and $1.5 \mathrm{hr}$ (fig. 4). The gastrocnemius explants (fig. 4A) from exercised animals incorporated 16,000 \pm 970 cpm after $1.0 \mathrm{hr}$, while control nonexercised gastrocnemius preparations incorporated $12,500 \pm$ 800 and $14,500 \pm 840 \mathrm{cpm}$ after 1.0 and $1.5 \mathrm{hr}$ of tissue incubation. The soleus muscle explants (fig. 4B) from exercised animals were significantly more active in protein synthesis only after $1.5 \mathrm{hr}$ of incubation, incorporating $19,500 \pm 630 \mathrm{cpm}$, while control explants incorporated $16,300 \pm 650 \mathrm{cpm}$ into protein. When the protein synthesis capacity of the tissue explants is expressed relative to the amount of RNA present, the same relative differences persist.

\section{DIscussion}

A significant amount of information is currently available regarding the synthesis of protein during the development of cardiac hypertrophy, despite the fact that some investigations are not entirely in agreement with respect to the role of protein synthesis during adaptation to increased functional demand. ${ }^{15}$ Little information is available concerning the role of the protein synthesis system during the adaptation of skeletal muscle to regularly performed, vigorous endurance training. The in-vitro techniques used in this investigation indicate that an increase in the efficiency of protein synthesis following a single bout of vigorous exercise may play a role in the development of increased capac- 


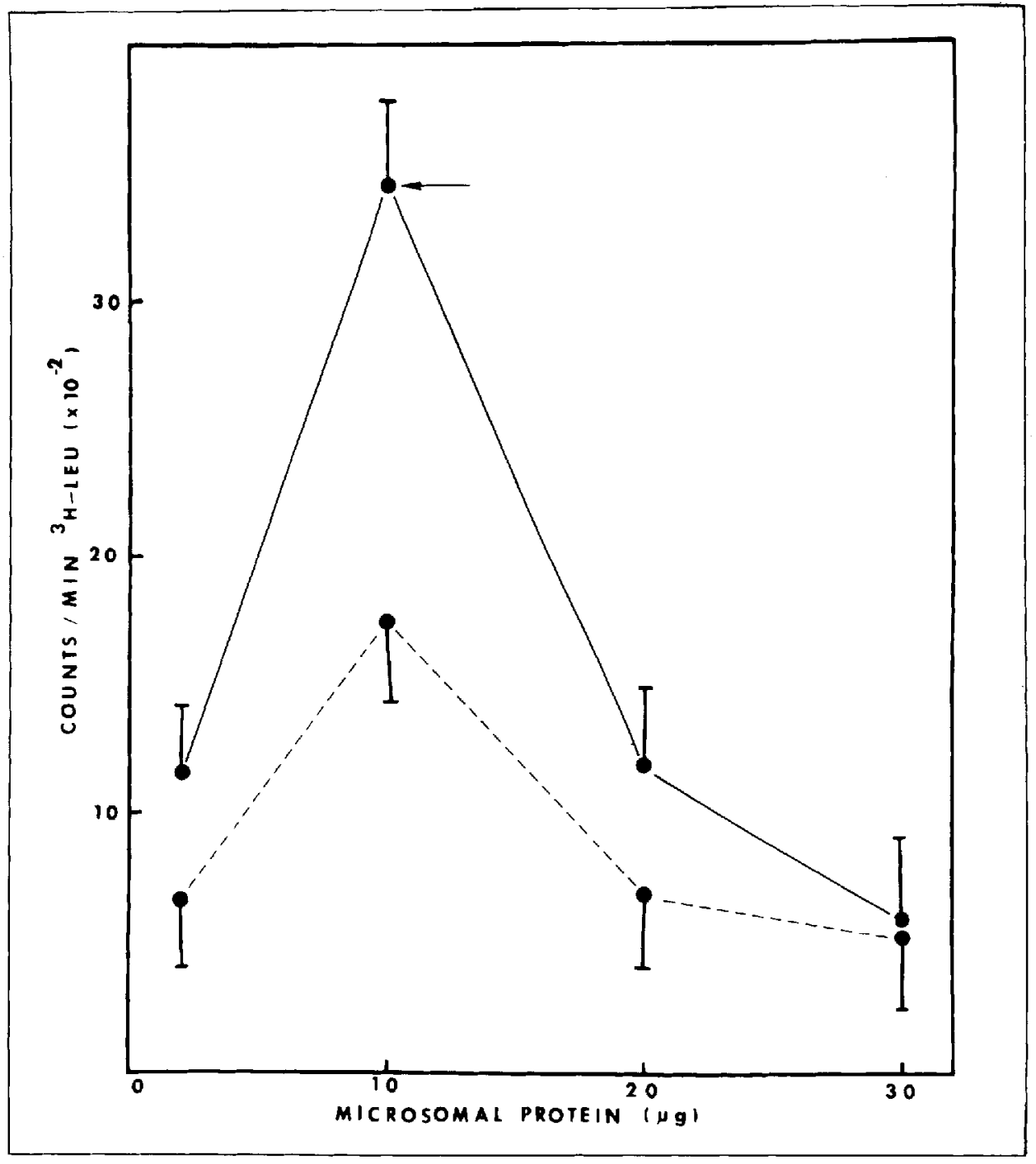

Figure 2. Incorporation of $\left[{ }^{3} \mathrm{H}\right]$ leucine into trichloroacetic acid-insoluble protein in a microsomal cell-free system derived from skeletal muscle cells. Values are mean \pm SEM for five preparations. Arrow indicates point which is significantly different at $p<0.01$. Control $(--)$ and exercised (__.) muscle microsomes.

ity for aerobic metabolism observed in endurancetrained skeletal muscle.

In-vitro polyribosomal and microsomal protein synthesis was enhanced in the skeletal muscle of the exercised animals. The results parallel the published finding that in-vitro microsomal protein synthesis is greater in hypertrophied skeletal muscle than in control muscle. ${ }^{2}$ The enhanced protein synthesis capacity has been attributed to an increase in microsomal RNA. Microsomes isolated from left ventricular tissue subsequent to supravalvular constriction of the ascending aorta in rabbits are more active than those isolated from control animals. This enhanced activity is detected after $24 \mathrm{hr}$ of overload stress and persists for five days. As in the case of hypertrophied skeletal muscle, the difference in activity was believed to be due to an increase in ribosomal RNA content of the microsome fraction of the stressed cardiac tissue. ${ }^{11}$ Other experiments using isolated, overloaded perfused cardiac tissue suggested that an increase in cardiac messenger RNA synthesis may be responsible for activation of microsomal protein synthesis. ${ }^{12}$

The results of our experiments with in-vitro protein synthesis by microsomes and polyribosomes from acutely exercised skeletal muscle indicate that exercise stress induces positive changes in the efficiency of protein synthesis at the level of translation, and that these changes in efficiency cannot be accounted for by quantitative differences in protein or RNA present in the in-vitro systems. The RNA contents of control and exercised microsomes and polysomes were equivalent, and the polyribosome profiles for control and exercised tissue were indistinguishable. The presence 


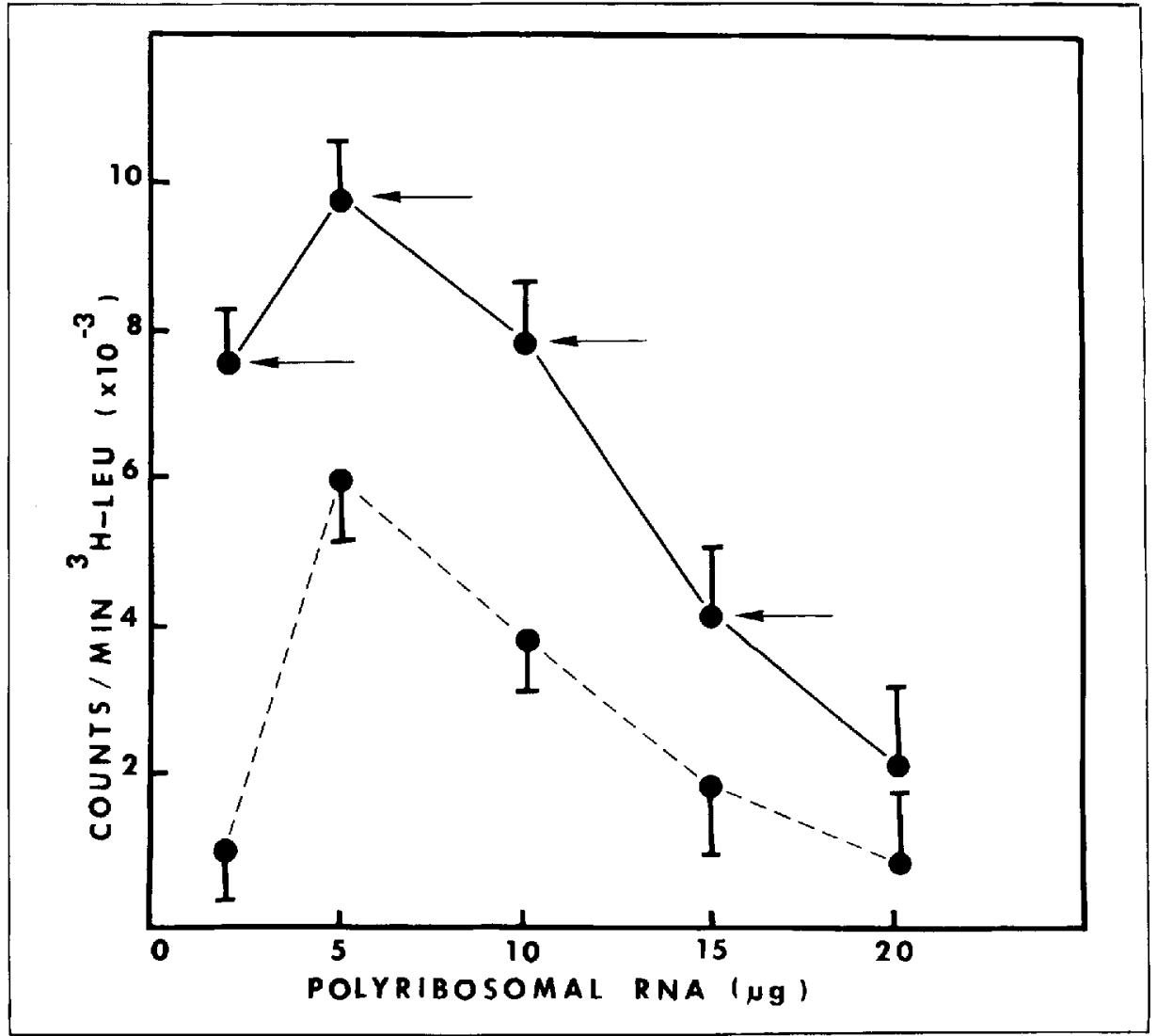

Figure 3. Incorporation of $\left[{ }^{3} \mathrm{H}\right]$ leucine into trichloroacetic acid-insoluble protein in a polyribosomal cell-free systern derived from skeletal muscle cells. Values are mean \pm SEM for five preparations. Arrows indicate points which are significantly different at $p<0.01$. Control (--) and exercised (-) muscle polyribosomes.

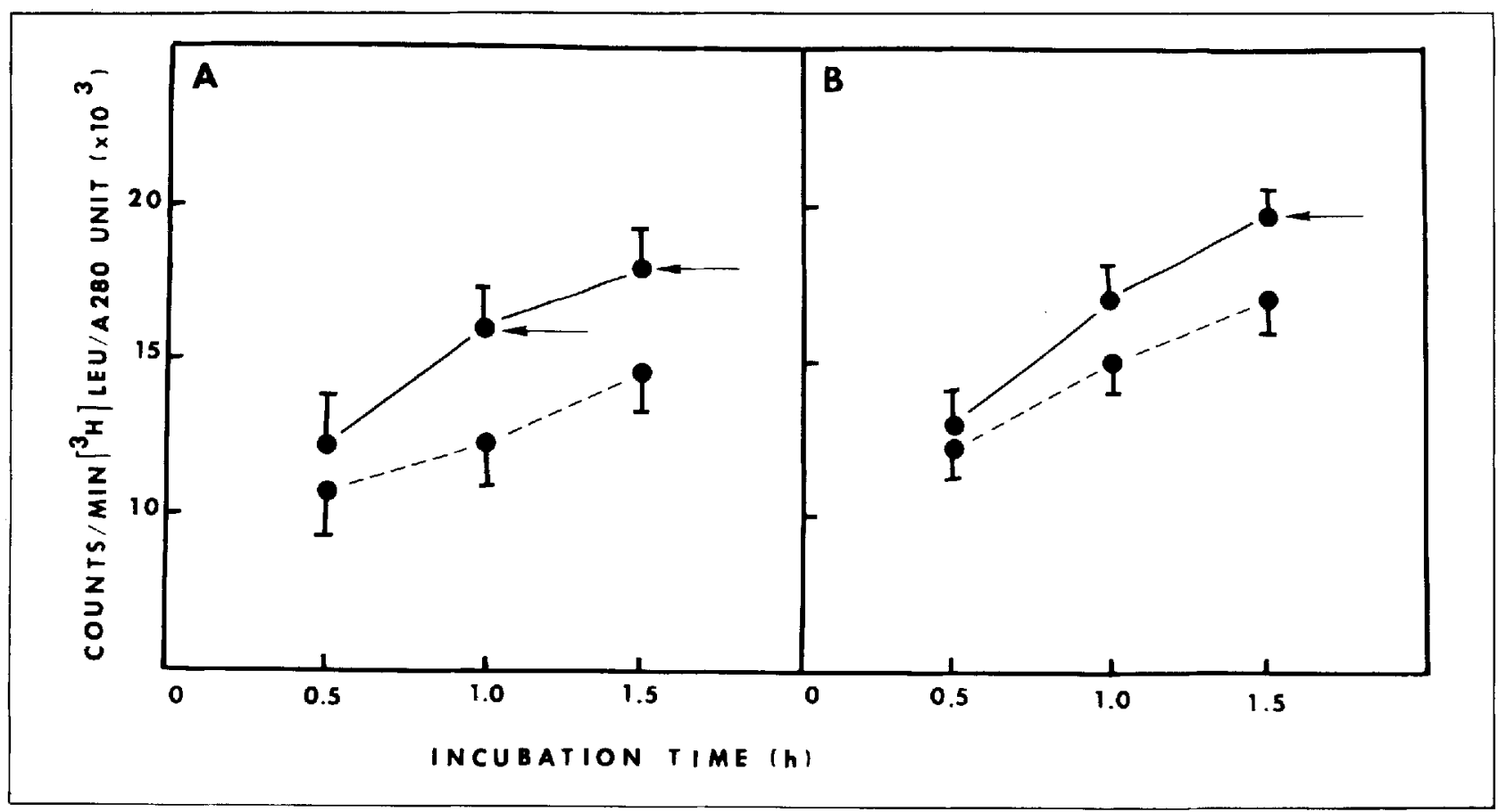

Figure 4. Time course of [ $\left.{ }^{3} \mathrm{H}\right]$-leucine incorporation into trichloroacetic acid-insoluble protein by gastrocnemius muscle explants $(A)$ and soleus muscle explants $(B)$ from guinea pigs. Values are mean \pm SEM for six preparations. Arrows indicate points which are significantly different at $p<0.01$. Control (---) ànd exercised (_) muscle explants. 
of small quantities of regulatory RNA or protein molecules cannot be excluded as a possible explanation of the results presented here, especially in view of the purification of a species of RNA that has been implicated in regulation of the translation of myosin messenger $\mathrm{RNA}^{4}{ }^{4}$ but it is clear that gross changes in the synthesis of stable RNA species cannot explain the results presented here.

Tissue explants from both the gastrocnemius and soleus muscles of exercised animals incorporated significantly more amino acids into protein than explants from control muscles after $1.0 \mathrm{hr}$ and $1.5 \mathrm{hr}$ of incubation in organ culture medium containing $\left[{ }^{3} \mathrm{H}\right]$-leucine. The results agree with the increased translational efficiency of polyribosomes and microsomes isolated from exercised skeletal muscle. The higher net amino acid incorporation by control and exercised soleus muscle explants, as compared with gastrocnemius muscle explants, is consistent with the finding that skeletal muscles containing a higher proportion of slow-twitch fibers are more active in protein synthesis and have a higher RNA concentration than do muscles with fewer slow-twitch fibers. ${ }^{1}$ The protein synthesis of the exercised gastrocnemius muscle explants is sig- nificantly greater than control values after $1.0 \mathrm{hr}$ of incubation, while explants of the exercised soleus muscle do not show any significant difference in protein synthesis until $1.5 \mathrm{hr}$ of incubation. These results may be explained by the difference in oxidative capacity between the two muscles. Compared to the gastrocnemius, the soleus muscle has a higher relative capacity for aerobic metabolism and demonstrates no significant adaptation to endurance training. ${ }^{5}$ Therefore, the high aerobic demand of the treadmill running is better met by the higher capacity for aerobic metabolism of the soleus muscle than by the gastrocnemius muscle.

Our results are in general agreement with the hypothesis that protein synthesis in skeletal muscle is correlated with the functional demands placed on that tissue. Extensions of these experiments, combined with efforts to isolate and translate messenger RNA from developmentally stable skeletal muscle, should enhance our understanding of the molecular mechanism(s) by which mature mammalian skeletal muscle is able to maintain its functional state as well as to adapt specifically to reduce relatively severe demands on its metabolic and contractile processes.

\section{REFERENCES}

1. Goldberg AL: Protcin synthesis in tonic and phasic skeletal muscle. Nature 216:1219-1220, 1967.

2. Hamosh M, Lesch M, Baron J, Kaufman S: Enhanced protein synthesis in a cell-free system from hypertrophied skeletal muscle. Science 157:935-937, 1967

3. Hay AM, waterlow JC: The effect of alloxan diabetes on muscle and liver protein synthesis in the rat measured by

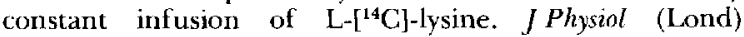
191:111P-112P, 1967.

4. Heywood SM, Kennedy DS: Purification of myasin translational control RNA and its interaction with myosin messenger RNA. Biochemistry 15:3314-3319, 1976.

5. Hollozy JO: Adaptation of skeletal muscle to endurance excrcise. Med Sci Sports 7:15j-164, 1975.

6. Ionasescu V: Distinction between Duchenne and other muscular dystrophies by ribosomal protein synthesis. / Med Genet 12:49-54, 1975.

7. Lowry OH, Rosenbrough NJ, Farr AL, Randall RJ: Protein measurement with the Folin phenol reagent. $J$ Biol Chem $193: 265-275,1951$

8. Malette I.E, Exton JH, Park CR: Control of gluconeogenesis from amino acids in the perfused rat liver. I Biol Chem 244:5713-5721, 1969.
9. Mejbaum W: Uber die Bestimmung kleiner Pentosemengen, insbesondere in Derivaten der Adenylsaure. Z Physiol Chem 258:117-120. 1939.

10. Millward DJ, Garlich PJ, James WPT, Nnanyelugo PO, Ryatt JS: Relationship between protein synthesis and RNA content in skeletal muscle. Nature 241:204-205, 1973.

11. Moroz I.A: Protein synthetic activity of heart microsomes and ribosomes during left ventricular hypertrophy in rabbits. Circ Res 21:449-459, 1967.

12. Schreiber SS, Oratz M, Evans C, Silver E, Rothschild MA: Effect of acute overload on cardiac muscle mRNA. $A m$ J Physiol 215:1250-1259, 1968.

13. Schreiber SS, Oratz M, Rothschild MA: Effect of acute overload on protein synthesis in cardiac muscle microsomes. Am I Physiol 213:1552-1555, 1967.

14. von der Dechen A. Olmstead PT: Protein-feeding of rats after protein starvation: incorporation of amino acid into polypeptide by skeletal muscle polyribosomes. $J$ Nutr 100:623-630, 1970.

15. Zimmer H-G, Stcinhopff G, Gerlach $\mathrm{E}$ : Changes in protein synthesis in the hypertrophying rat heart. Pfuegers Arch $336: 311-325,1972$. 